\title{
The Effects of Sodium Fluoride on Calcium Metabolism of Subjects with Metabolic Bone Diseases *
}

\author{
Clayton Rich, John Ensinck, and Peter Ivanovich \\ (From the Department of Medicine, University of Washington School of Medicine, and the \\ Radioisotope Service, Veterans Administration Hospital, Seattle, Wash.)
}

After the initial description of skeletal fluorosis (1), Roholm in 1937 (2) reported a study of 68 cryolite miners, of whom 50 had slight or moderate osteosclerosis. Seven others, who had advanced skeletal changes, also had calcification of the ligaments and tendinous insertions, particularly of the vertebral column. Minor gastrointestinal and joint symptoms were frequent, but except for restricted mobility of the spine of the most severely affected workers, physical examination and tests of urine and peripheral blood were unremarkable. These findings led Roholm to characterize osteosclerosis in this group of subjects as "fairly benign.” It has since been amply confirmed that osteosclerosis can result from prolonged exposure to fluoride and that subjects with minimal or moderate osteosclerosis are usually asymptomatic and in good general health (3).

This leads to the consideration that salts of fluorine might be used as treatment of patients with osteoporosis to cause a degree of osteosclerosis that would strengthen the skeleton but not lead to other changes. This report describes the results of studies of the effect of fluoride on subjects with metabolic bone diseases. Although our main interest in undertaking an evaluation of this problem has been in the possible therapeutic effect of fluoride in osteoporosis, we have studied also its effect in subjects with Paget's disease, because of the possibility that fluoride would suppress the increased osteoclastic activity and thereby retard progression of this disease. We have

* Submitted for publication September 16, 1963; accepted November 21, 1963.

These studies were supported in part by a grant (A 4701) from the National Institute of Arthritis and Metabolic Diseases of the U. S. Public Health Service.

A portion of this work was conducted through the Clinical Research Center facility of the University of Washington, supported by the National Institutes of Health (grant OG-13). found that calcium retention is brought about in most subjects given 40 to $75 \mathrm{mg}$ fluoride ion per day, but usually only after 2 to 3 months of treatment. These results extend our earlier, brief reports $(4,5)$ and are consistent with those recently described by Purves (6) and in a preliminary report by Bernstein and co-workers (7).

\section{Clinical Material and Methods}

Thirteen balance studies of 3 to 14 weeks were carried out on six patients. Clinical summaries are given in the appendix. Patients were admitted to the metabolic ward of the Clinical Research Center, University Hospital, and placed upon a diet calculated to provide an almost constant daily intake of calories, protein, fat, calcium, and phosphorus. Food was purchased in large lots to reduce variation because of differences in composition from lot to lot. Two or three daily menus were repeated regularly throughout the hospital stay, and one duplicate of each menu was analyzed each week. All urine and stools were collected separately and refrigerated until analyzed. Charcoal or carmine was given orally at the start of each balance period and its appearance in stool used as an indication of the delay in transit of food through the gastrointestinal tract.

The first balance period was not started until after the patient had been 2 weeks on the diet. Four or five 1 -week periods of balance measurement were made, and a number of clinical studies were carried out as a base line for comparison when repeated during treatment with sodium fluoride (Table I). Thereafter, patients were treated with 0.7 to $1.4 \mathrm{mg}$ fluoride per $\mathrm{kg}$ body weight per day, given orally as sodium fluoride, either in solution or in enteric-coated tablets. In some studies, continuous balance measurements were made for the first 6 to 9 weeks of treatment. In other instances, patients were discharged as soon as treatment was started and, while continuously under treatment with fluoride, were readmitted for repeat balance and clinical studies.

Stool and diet collections were homogenized and weighed. Weighed samples were reduced to ash at $600^{\circ} \mathrm{C}$ in a muffle furnace, the ash was dissolved in $\mathrm{HCl}$, water was added, and the $\mathrm{pH}$ was brought to 4.5 . Ammonium oxalate was then added to cause a calcium oxalate precipitate, which was collected. Calcium oxalate precipitates were prepared also from samples of urine. 
TABLE I

Results of clinical chemical testing of patients

\begin{tabular}{|c|c|c|c|c|c|c|c|}
\hline \multirow{4}{*}{$\begin{array}{l}\text { Diagnosis: } \\
\text { Patient: } \\
\text { Study period: }\end{array}$} & & \multicolumn{6}{|c|}{ Primary osteoporosis } \\
\hline & & \multicolumn{3}{|c|}{ M.H. } & \multicolumn{3}{|c|}{ F.F. } \\
\hline & & \multirow{2}{*}{ Control } & \multicolumn{2}{|c|}{ Treatment } & \multirow[t]{2}{*}{ Control } & \multicolumn{2}{|c|}{ Treatment } \\
\hline & & & 1 & 2 & & 1 & 2 \\
\hline $\begin{array}{l}\text { Weeks of treatment } \\
\text { Doselof fluoride } \\
\text { Total dose of fluoride }\end{array}$ & $\begin{array}{l}\mathrm{mg} / \text { day } \\
\mathrm{g}\end{array}$ & & $\begin{array}{l}1-7 \\
50 \\
2.5\end{array}$ & $\begin{array}{l}32-36 \\
50 \\
13\end{array}$ & & $\begin{array}{l}30-34 \\
50 \\
11.9\end{array}$ & $\begin{array}{l}72-75 \\
40 \\
24.8\end{array}$ \\
\hline $\begin{array}{l}\text { Height } \\
\text { Weight }\end{array}$ & $\begin{array}{l}\mathrm{cm} \\
\mathrm{kg}\end{array}$ & $\begin{array}{r}156 \\
49\end{array}$ & & 153 & $\begin{array}{r}167 \\
55\end{array}$ & & 167 \\
\hline $\begin{array}{l}\text { Test (average of all values) } \\
\text { Plasma calcium } \\
\text { Plasma phosphorus } \\
\text { Serum alkaline phosphatase } \\
\text { Serum acid phosphatase } \\
\text { Packed cell volume } \\
\text { Leukocyte count } \\
\text { Urinalysis } \\
\text { Creatinine or (BUN) } \\
\text { Clearance: creatinine or (BUN) } \dagger \\
\text { P.S.P. excretion } \dagger \\
\text { Fasting blood sugar } \dagger \\
\text { B.S.P. excretion } \dagger \\
\text { Serum glutamine oxalate trans- } \\
\text { aminase } \dagger \\
\text { Absorption of dietary fat } \\
\text { Urine hydroxyproline }\end{array}$ & $\begin{array}{l}\mathrm{mg} / 100 \mathrm{ml} \\
\mathrm{mg} / 100 \mathrm{ml} \\
\text { King-Armstrong } \mathrm{U} \\
\mathrm{U} / 100 \mathrm{ml} \\
\% \\
10^{3} / \mathrm{mm}^{3} \\
\mathrm{mg} / 100 \mathrm{ml} \\
\mathrm{ml} / \mathrm{min} \\
\% \text { in } 1 \mathrm{hr} \\
\mathrm{mg} / 100 \mathrm{ml} \\
\% \text { in } 45 \mathrm{~min} \\
\mathrm{U} / 100 \mathrm{ml} \\
\% \text { of intake } \\
\mathrm{mg} / 24 \mathrm{hr}\end{array}$ & $\begin{array}{c}10.2 \\
3.4 \\
8.7 \\
0.18 \\
41 \\
4.9 \\
\ddagger \\
(24) \| \\
(20) \\
68 \\
74 \\
26\end{array}$ & $\begin{array}{c}9.5 \\
3.1 \\
8.7 \\
0.27 \\
37 \\
5.6 \\
\ddagger\end{array}$ & $\begin{array}{c}9.8 \\
3.1 \\
8.4 \\
0.34 \\
38 \\
5.0 \\
\ddagger \\
+ \\
(23) \\
(88) \\
39 \\
\\
21\end{array}$ & $\begin{array}{c}8.8 \\
3.3 \\
6.6 \\
0.51 \\
50 \\
6.0 \\
\ddagger \\
0.8\end{array}$ & $\begin{array}{c}9.3 \\
3.5 \\
9.1 \\
0.86 \\
49 \\
6.5 \\
\vdots \\
1.0 \\
83 \\
88 \\
90 \\
2\end{array}$ & $\begin{array}{c}9.4 \\
3.3 \\
5.5 \\
0.68 \\
49 \\
6.4 \\
\ddagger \\
0.9 \\
133 \\
72\end{array}$ \\
\hline
\end{tabular}

* $\mathrm{BUN}=$ blood urea nitrogen; P.S.P. = phenolsulfonphthalein; B.S.P. = bromosulfaphthalein. † Obtained once or twice in each study period; other values were usually determined each week. $\ddagger$ Normal.

These precipitates were dissolved in $\mathrm{HCl}$, and the calcium was measured by titration with Versene (ethylenediaminetetraäcetic acid tetrasodium salt) as previously described (8), except that an automatic titrating and recording system was used. Addition of $100 \mathrm{mg}$ of fluoride to the starting sample (1-day collection of urine or stool) or $200 \mu \mathrm{g}$ fluoride to the final sample (which contained 30 to $70 \mu \mathrm{g}$ calcium) did not affect this analysis. Calcium in plasma was analyzed directly by titration with Versene (8). Stool and urine nitrogen was measured by the micro-Kjeldahl method (9), phosphate by the method of Fiske and Subbarow (10), urine creatinine by the Jaffe reaction (9), hydroxyproline by the method of Prockop and Udenfriend (11), and stool fat by conversion to fatty acid and extraction and titration of the resulting acidity (12). Fluoride was measured after perchloric acid distillation of samples of diet, stools, or urine (13) by reaction with a zirconium lake (14).

Balance results and theoretical balance of phosphorous were calculated and charted according to the method of Reifenstein, Albright, and Wells (15), with slight modification of the scales used for charting. The intake is charted down from the zero line, stool up from intake, and urine above stool, so that a positive balance is present when the sum of stool and urine excretion does not reach the zero line.

\section{Results}

Balance studies. Figure 1 illustrates the results of studies of M.H., including changes in balance of calcium, phosphate, nitrogen, and fluoride. There was little change of calcium balance during the first 7 weeks of treatment, but after 32 weeks of treatment definite calcium retention was present. (As in all other studies, the patient had been on the metabolic diet for 2 weeks before the first balance measurement.) Phosphate balance reflected similar changes, while nitrogen balance was only slightly altered. There was a striking initial drop in the rate of excretion of calcium in urine, from control values of $112 \mathrm{mg}$ per day to $17 \mathrm{mg}$ per day during the second and third weeks of treatment, but 6 months later, when the maximal change of calcium balance was found, excretion of calcium in urine was the same as it had been before treatment. Fecal calcium was reduced during both periods of study during treatment. 
TABLE I

before and during treatment with sodium fluoride*

\begin{tabular}{|c|c|c|c|c|c|c|c|c|c|}
\hline \multicolumn{6}{|c|}{ Primary osteoporosis } & \multirow{2}{*}{\multicolumn{2}{|c|}{$\frac{\text { Steroid osteoporosis }}{\text { H.L. }}$}} & \multirow{2}{*}{\multicolumn{2}{|c|}{$\frac{\text { Paget's disease }}{\text { E.M. }}$}} \\
\hline \multicolumn{2}{|c|}{ A.S. } & \multicolumn{2}{|c|}{ R.K., study 1} & \multicolumn{2}{|c|}{ R.K., study 2} & & & & \\
\hline Control & Treatment & Control & Treatment & Control & Treatment & Control & Treatment & Control & Treatment \\
\hline & $\begin{array}{c}1-9 \\
50 \\
3.0\end{array}$ & & $\begin{array}{c}1-5 \\
80-100 \\
3.1\end{array}$ & & $\begin{array}{c}28-32 \\
50 \\
11.2\end{array}$ & & $\begin{array}{l}31-35 \\
75 \\
18.4\end{array}$ & & $\begin{array}{l}40-45 \\
60 \\
21.4\end{array}$ \\
\hline $\begin{array}{r}168 \\
50\end{array}$ & 168 & $\begin{array}{r}167 \\
71\end{array}$ & & & 167 & $\begin{array}{r}177 \\
85\end{array}$ & 177 & $\begin{array}{r}148 \\
60\end{array}$ & 148 \\
\hline $\begin{array}{c}10.6 \\
3.5 \\
4.5 \\
0.63 \\
45 \\
10.8 \\
\S \\
1.1 \\
(41) \\
65 \\
105 \\
12\end{array}$ & $\begin{array}{c}9.4 \\
2.9 \\
5.4 \\
0.20 \\
43 \\
10.6 \\
\$\end{array}$ & $\begin{array}{c}10.5 \\
3.7 \\
5.7 \\
0.22 \\
45 \\
8.6 \\
\vdots \\
(14) \\
(41)\end{array}$ & $\begin{array}{c}10.6 \\
3.4 \\
7.4 \\
0.28 \\
39 \\
7.3 \\
\ddagger\end{array}$ & $\begin{array}{c}10.1 \\
2.6 \\
5.7 \\
0.22 \\
50 \\
7.1 \\
\ddagger \\
(21) \\
60 \\
67 \\
92 \\
18 \\
52\end{array}$ & $\begin{array}{c}10.0 \\
2.2 \\
7.4 \\
0.28 \\
51 \\
8.2 \\
\ddagger \\
(18) \\
(47) \\
52 \\
87 \\
9\end{array}$ & $\begin{array}{c}10.2 \\
2.9 \\
4.9 \\
0.36 \\
48 \jmath \\
9.5 \\
\ddagger \\
(12) \\
118 \\
83 \\
94 \\
8 \\
20\end{array}$ & $\begin{array}{c}9.6 \\
2.3 \\
5.7 \\
0.30 \\
45 \\
7.4 \\
\ddagger \\
(11) \\
120 \\
59 \\
66 \\
9 \\
11\end{array}$ & $\begin{array}{c}10.2 \\
3.2 \\
30.2 \\
0.54 \\
40 \\
7.9 \\
\ddagger \\
(15) \\
(57) \\
37 \\
69 \\
6 \\
15\end{array}$ & $\begin{array}{c}9.4 \\
3.7 \\
29.2 \\
0.17 \\
41 \\
7.0 \\
\vdots \\
(19) \\
(97) \\
73 \\
72 \\
4\end{array}$ \\
\hline $\begin{array}{l}96 \\
24.2\end{array}$ & $\begin{array}{l}95 \\
24.1\end{array}$ & $\begin{array}{l}98 \\
23.3\end{array}$ & $\begin{array}{l}96 \\
33.8\end{array}$ & $\begin{array}{l}96 \\
40.0\end{array}$ & $\begin{array}{l}95 \\
41.5\end{array}$ & $\begin{array}{l}89 \\
37.0\end{array}$ & $\begin{array}{l}88 \\
40.3\end{array}$ & $\begin{array}{r}96 \\
176\end{array}$ & $\begin{array}{r}96 \\
134\end{array}$ \\
\hline
\end{tabular}

$\S$ Leukocytes, few granular casts.

II Numbers in parentheses refer to BUN.

Figure 2 shows similar results in a second patient, F.F., studied twice during $1 \frac{1}{2}$ years of treatment. There was moderate calcium retention 30 and 72 weeks after starting treatment not associated, in this patient, with reduction of calcium in urine, but instead, with some decrease in the amount of calcium in stools. The apparently negative phosphorus balance was associated with nitrogen loss, as shown by the theoretical balance, which agreed with that found by analysis.

A third subject with primary osteoporosis, R.K., was studied during two courses of treatment of fluoride and showed no response (Figure 3 ). The first study was carried out while he was given an intake of $200 \mathrm{mg}$ calcium per day. He had definitely increased excretion of fat and nitrogen in stool (Figure 3) accompanied by aching epigastric pain and diarrhea when he was given $1.4 \mathrm{mg}$ fluoride per $\mathrm{kg}$ per day during the first 2 weeks of treatment. These symptoms and chemical evidence of absorptive difficulty disappeared when the dose was reduced. The rate of cal- cium excretion in urine, low during the control period, diminished even further during treatment, but the over-all balance of calcium was unchanged. This result was not unexpected, because of the short duration of treatment. Similar changes in excretion of calcium in urine, but lack of effect upon calcium balance, were observed 8 months later when the patient was re-treated at a time when he had a normal calcium intake.

The balance results for all patients studied are summarized in Table II. In this table, the average balance for the entire 28 days (four periods) of the pretreatment study is compared to the last 28 days of each balance measurement made during treatment (except for the final study of F.F., where only three periods of balance study were measured). This shows the data already commented upon and results of the three other studies described below.

A.S., a fourth patient with primary osteoporosis, was treated with fluoride for only 9 weeks without change in calcium balance. 
A subject with steroid osteoporosis (H.L.) was treated with fluoride for 31 weeks before the second balance study but had substantial increase of his dose of prednisone, from $20 \mathrm{mg}$ per day before treatment to $30 \mathrm{mg}$ per day during most of the period of treatment with fluoride. It is probable that this may have influenced the results, a speculation supported because of increased calcuria, which has not been seen in any other patient treated with fluoride but which is the usual result of glucocorticoid therapy.

Balance measurements were performed also on E.M., a patient with Paget's disease, for 5 weeks before and after 28 weeks of treatment with fluoride. There was slight reduction of calcium in urine and stools and slight, but significant, change of calcium balance from an average of 64-mg loss per day in the control period to reten- tion of $45 \mathrm{mg}$ per day. Phosphorus and nitrogen balances did not change.

The calcium balances recorded in Table II are shown by the closed circles in Figure 4. The open circles show the results from previous work calculated in the same way (4). This gives our total present experience in testing the effect of fluoride in the dose used in this study. Significant calcium retention was not observed during the first 8 to 10 weeks of treatment with fluoride. Of the eight subjects treated for 10 or more weeks, four had primary osteoporosis, two had steroid-induced osteoporosis, and two had Paget's disease. The results in these different states are as follows:

a) Primary osteoporosis. Three of four subjects retained more calcium during treatment than during the control period, the average positive change in these three being $138 \mathrm{mg}$ per day. Two

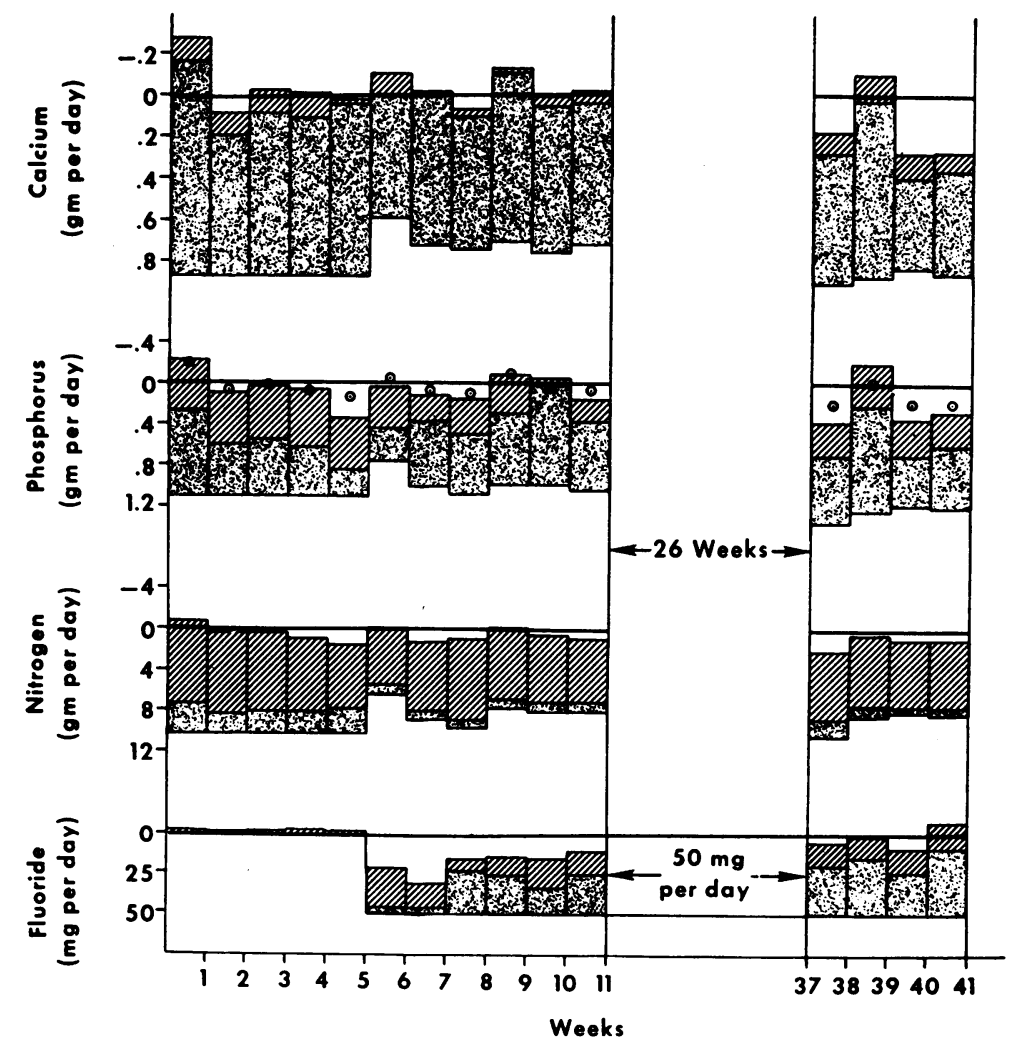

Fig. 1. Results of balance study of M.H., an 84-year-old woman WITH PRIMARY OSTEOPOROSIS. Treatment with fluoride was continued at the dose shown during the period between the first and second study. $10 \mathrm{ml}$ aluminum hydroxide gel was given twice a day after the second week of treatment until the end of the final study. Theoretical balance of phosphorus is indicated by the circles. 


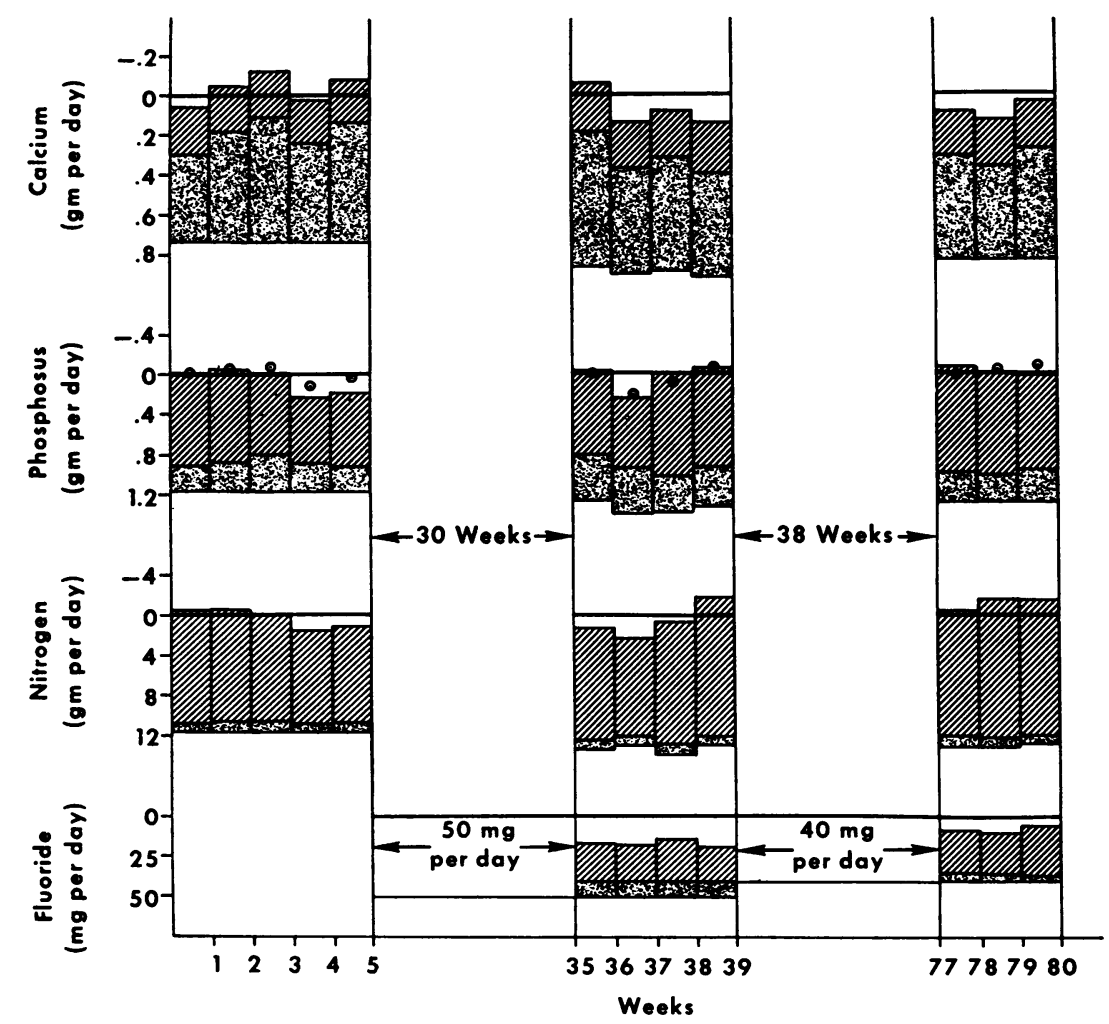

Fig. 2. Results of Balance study of F.F., a 62-year-old Man with PRiMARY OSTEOPOROSIS. Treatment with fluoride was started at the end of the first period of study and continued thereafter.

patients were elderly postmenopausal females and the other (F.F.) was a male with what classically is called idiopathic osteoporosis, a severe form of osteoporosis with early onset, said not to respond to any commonly used form of therapy (16).

b) Steroid osteoporosis. One subject retained $100 \mathrm{mg}$ additional calcium per day during treatment with fluoride; the other (H.L.), whose dose of prednisone was increased during the period of fluoride administration and who had diminished fat absorption before and during treatment with fluoride, did not respond.

c) Paget's disease. Both subjects showed calcium retention (the average was $149 \mathrm{mg}$ per day), and one (W.T.) experienced marked relief of symptoms and fall of alkaline phosphatase activity during treatment.

Except where the fluoride was poorly absorbed, as with M.H., whose fecal excretion increased when aluminum hydroxide gel was given (Figure 1), the amount of fluoride in stools re- mained low. Excretion in urine, however, equal to less than half the amount given during the first few weeks of treatment, usually rose during continued treatment (Figures 2 and 3 ), so that the gross retention of fluoride diminished. In spite of this tendency, very substantial amounts of fluoride were retained by all but one of the subjects, even after 30 to 75 weeks of treatment. As shown in Table II, the average positive balance of the four subjects studied after about 30 weeks of treatment was $18 \mathrm{mg}$ per day, equal to one-third of the dose given. The only subject studied after a much longer period of treatment (F.F.) retained half as much at 72 as he had at 30 weeks.

Other studies. The values for calcium, phosphorus, and alkaline and acid phosphatase of plasma, as well as tests of renal, hematologic, hepatic, and other systemic functions, obtained periodically throughout treatment of all patients, showed no significant alteration from control values. The averages of the results of these tests are shown in Table I. Fat balance was meas- 
TABLE II

Average of results of balance studies during the last four periods

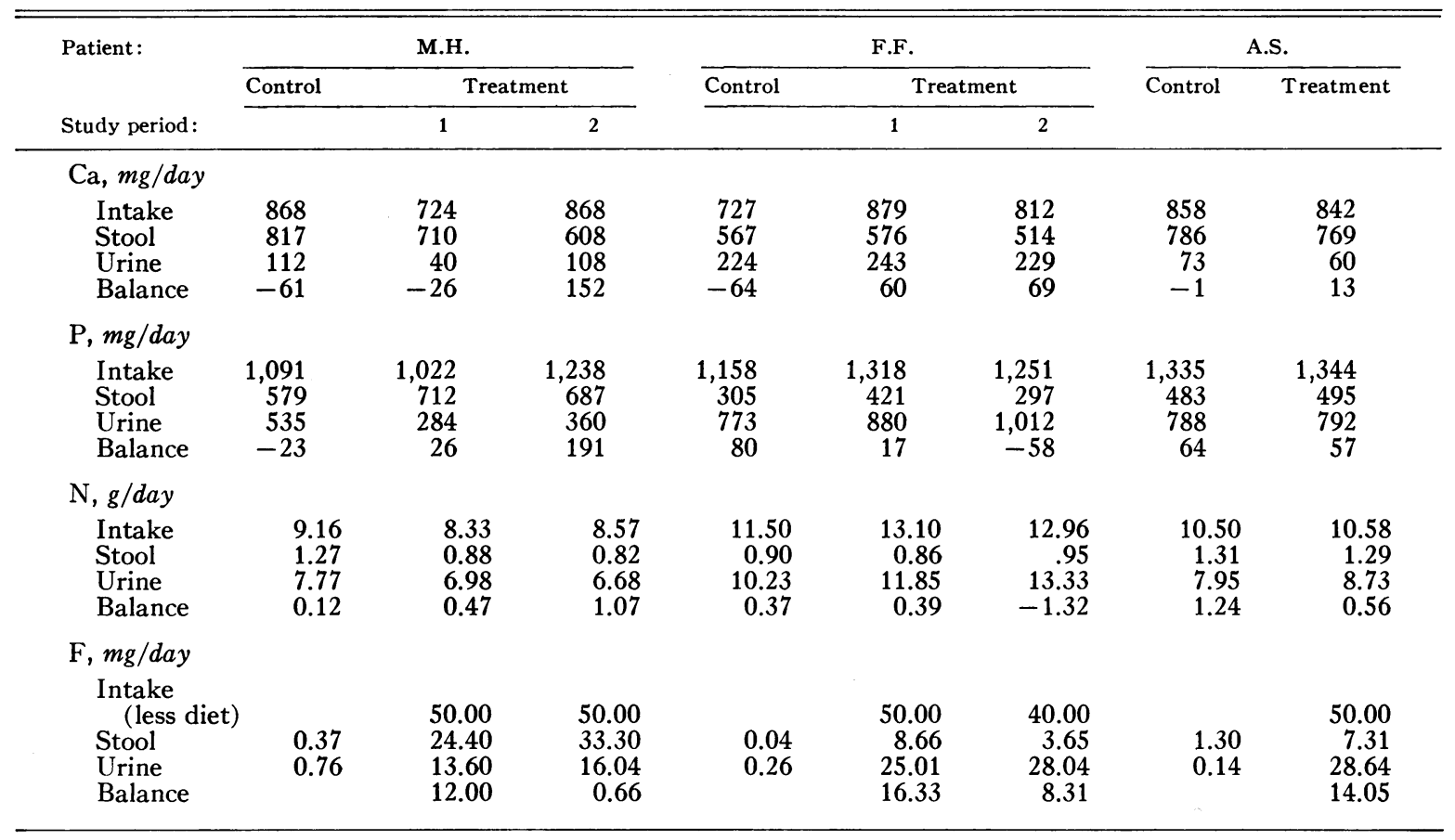

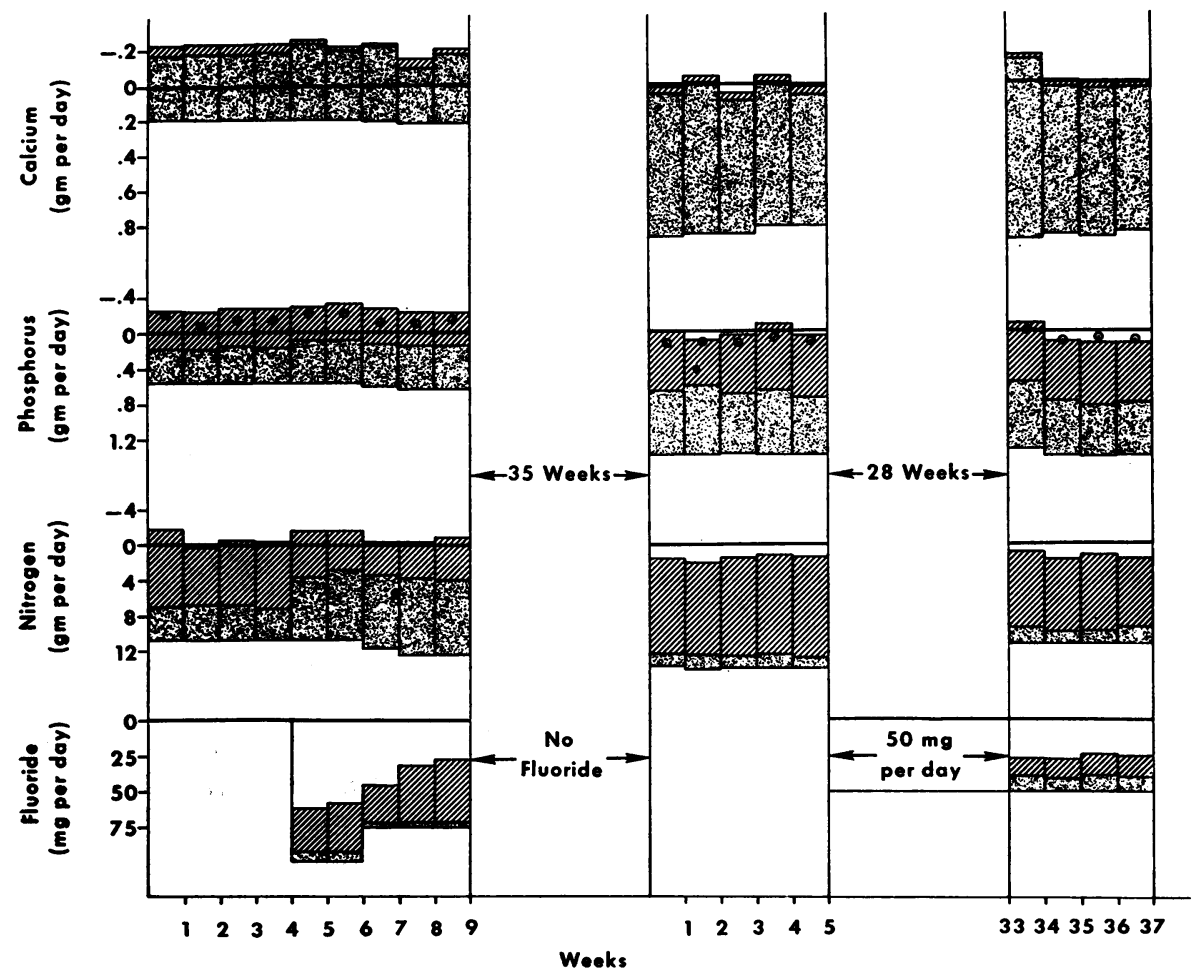

Fig. 3. Results of balance STUdy of R.K., a 70-yeAR-OLd MAN With PRIMARy osteoPORosis. Sodium fluoride was given for 5 weeks during the first study period and was then stopped for $\mathbf{4 0}$ weeks. It was started again at the end of the second control study and continued thereafter. 
TABLE II

(28 days) of control study and treatment with sodium fuoride

\begin{tabular}{|c|c|c|c|c|c|c|c|}
\hline \multicolumn{2}{|c|}{ R.K., study 1} & \multicolumn{2}{|c|}{ R.K., study 2} & \multicolumn{2}{|c|}{ H.L. } & \multicolumn{2}{|c|}{ E.M. } \\
\hline Control & Treatment & Control & Treatment & Control & Treatment & Control & Treatment \\
\hline $\begin{array}{r}187 \\
371 \\
56 \\
-240\end{array}$ & $\begin{array}{r}206 \\
386 \\
15 \\
-195\end{array}$ & $\begin{array}{r}827 \\
794 \\
40 \\
-7\end{array}$ & $\begin{array}{r}859 \\
871 \\
24 \\
-36\end{array}$ & $\begin{array}{r}802 \\
761 \\
301 \\
-260\end{array}$ & $\begin{array}{r}944 \\
797 \\
454 \\
-307\end{array}$ & $\begin{array}{r}851 \\
720 \\
196 \\
-65\end{array}$ & $\begin{array}{r}840 \\
676 \\
119 \\
45\end{array}$ \\
\hline $\begin{array}{r}561 \\
391 \\
437 \\
-267\end{array}$ & $\begin{array}{r}615 \\
484 \\
391 \\
-260\end{array}$ & $\begin{array}{r}1,370 \\
689 \\
654 \\
27\end{array}$ & $\begin{array}{r}1,391 \\
641 \\
676 \\
74\end{array}$ & $\begin{array}{r}1,690 \\
1,707 \\
75 \\
-92\end{array}$ & $\begin{array}{r}1,511 \\
1,489 \\
3 \\
19\end{array}$ & $\begin{array}{r}1,170 \\
532 \\
603 \\
35\end{array}$ & $\begin{array}{r}1,195 \\
499 \\
673 \\
23\end{array}$ \\
\hline $\begin{array}{r}10.67 \\
3.78 \\
7.12 \\
-.23\end{array}$ & $\begin{array}{r}11.88 \\
4.29 \\
8.39 \\
-.80\end{array}$ & $\begin{array}{r}14.09 \\
1.50 \\
10.97 \\
1.62\end{array}$ & $\begin{array}{r}11.58 \\
1.96 \\
8.26 \\
1.36\end{array}$ & $\begin{array}{r}16.56 \\
2.16 \\
14.31 \\
0.09\end{array}$ & $\begin{array}{r}16.19 \\
1.82 \\
13.41 \\
0.96\end{array}$ & $\begin{array}{r}11.04 \\
1.13 \\
9.29 \\
0.62\end{array}$ & $\begin{array}{r}10.92 \\
1.40 \\
8.64 \\
0.88\end{array}$ \\
\hline $\begin{array}{l}0.16 \\
0.05\end{array}$ & $\begin{array}{r}85.00 \\
7.26 \\
36.60 \\
41.14\end{array}$ & $\begin{array}{l}0.17 \\
0.07\end{array}$ & $\begin{array}{r}50.00 \\
9.52 \\
14.75 \\
25.73\end{array}$ & & $\begin{array}{l}75.00 \\
25.67 \\
27.34 \\
21.99\end{array}$ & $\begin{array}{l}0.15 \\
0.22\end{array}$ & $\begin{array}{l}60.00 \\
19.73 \\
11.61 \\
28.66\end{array}$ \\
\hline
\end{tabular}

ured as an indication of whether or not fluoride reduced gut absorptive ability, but was not consistently altered. No change in appearance of $\mathrm{X}$-ray films of the skull, vertebrae, chest, pelvis, or long bones was found in any patient.

Only two symptoms, epigastric distress and joint pain, have been encountered in subjects given fluoride. Most patients who take more than 10 $\mathrm{mg}$ fluoride in solution at one time experience aching epigastric pain occurring within a minute and lasting about 30 minutes. It is decreased if fluoride is given after a meal and abolished if fluoride is given after aluminum hydroxide gel, calcium carbonate, or in enteric-coated tablets.

Three patients (R.K., H.L., and E.M.) experienced aching joint pain in the knees or ankles upon weight bearing. This symptom started gradually after several months of treatment, and persisted until fluoride was discontinued, after which it slowly disappeared. The pain was present only upon weight bearing, was moderately severe, and definitely reduced the subjects' physical activity. There was no effusion, restriction of motion, tenderness, or change in X-ray findings. Each of these patients gave a history of inter- mittent aching joint pain for many years before treatment.

\section{Discussion}

Dose and toxicity. Although many studies of fluoride effect have been carried out in lower mammals and man, relatively few describe the effect of doses such as we have used, or report data which allow an estimate of the lower limit of toxicity for humans (2, 3). Black, Kleiner, and Bolker found no evidence of toxicity in 60 human subjects treated for as long as 6 months with an average daily dose of $320 \mathrm{mg} \mathrm{NaF}$, equal to $2.4 \mathrm{mg}$ fluoride per $\mathrm{kg}$ per day for a $60-\mathrm{kg}$ subject (17). Others, however, have considered this dose rate to be toxic when given for prolonged periods to humans or small mammals (18).

A second consideration in giving fluoride to patients is duration of treatment. Roholm found sclerosis only in subjects who had been exposed to fluoride for more than 5 years and found advanced changes only after 10 years of exposure (the average being 20 years). The suggestion that progressive changes occur with prolonged exposure is given weight by reports of crippling 


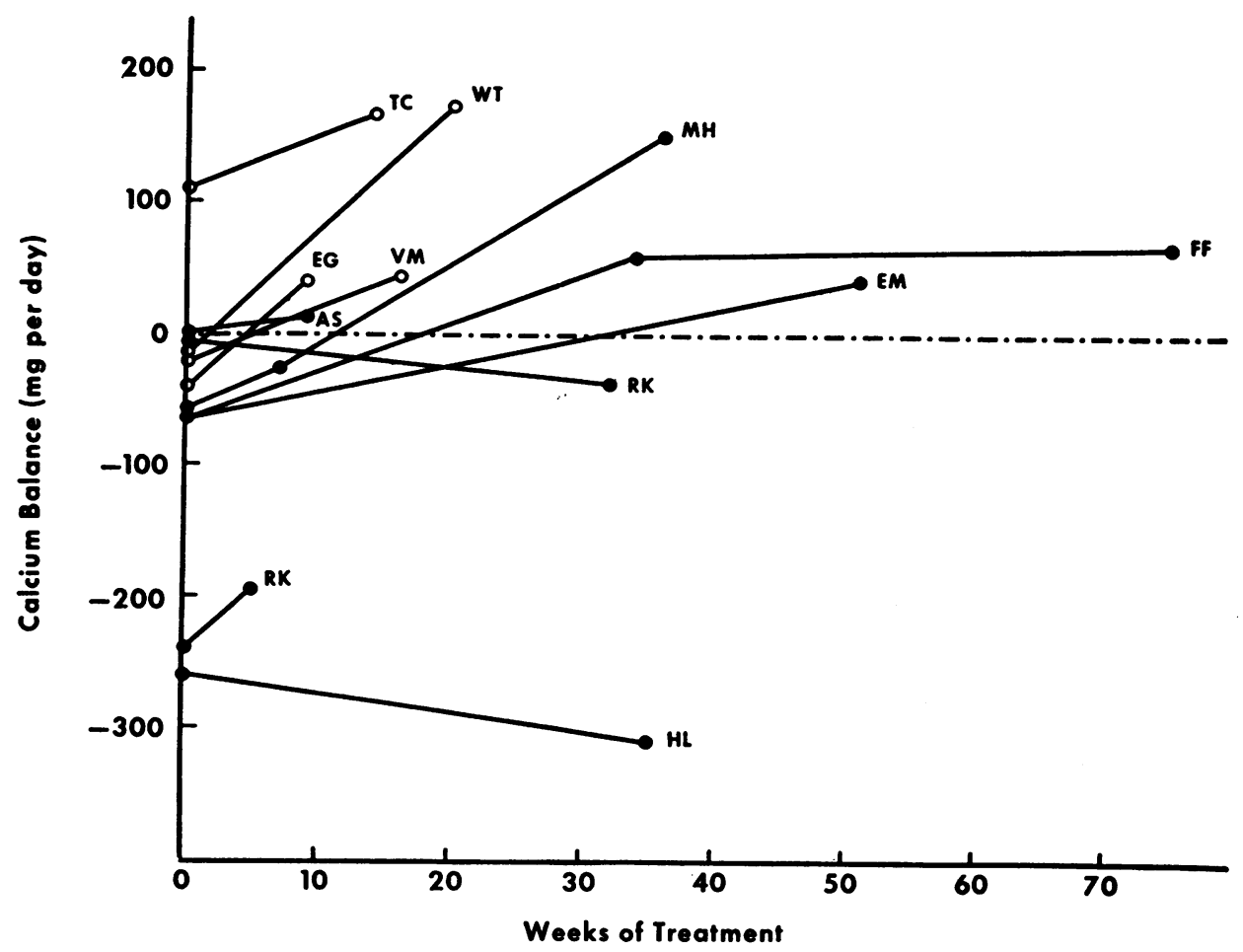

Fig. 4. Sum mary of measurements of Calcium balance of all SUbJects So far treated WITH ABOUt 1 Mg FluORIDE PER KG BODY WEIGHT PER DAY. Closed circles are for patients described in this study and open circles are for those reported previously (4). The abscissa gives weeks between the end of the control study and the end of any period of study during treatment. On the ordinate is shown the average calcium balance during the last 4 weeks of the control period and of each period of balance measurement during treatment.

fluorosis from several areas of Asia where lifelong exposure to fluoride in drinking water and dust eaten with food occurs (19). Thus, if fluoride is to be used in a therapeutic trial, both the dose and duration of treatment must be controlled.

It was possible to calculate, from the amount of fluoride found by Roholm in the skeleton of two autopsied osteosclerotic patients (2), and because about half of an oral dose is retained (3), that his subjects ingested at least $0.3 \mathrm{mg}$ fluoride per $\mathrm{kg}$ body weight per day. We treated our first patients for relatively short periods with this dose but found no effect on calcium metabolism (4) and have since given about $1.0 \mathrm{mg}$ fluoride per $\mathrm{kg}$ per day. At this dose rate, we have found no evidence of nonskeletal effects (clinical, chemical, or radiographic), except for the two symptoms already described. The epigastric pain, which occurs immediately and is abolished by measures which reduce gastric acidity or by use of entericcoated tablets, presumably is from a direct action of fluoride on the gastric mucosa. One subject who took a higher dose, $1.4 \mathrm{mg}$ per $\mathrm{kg}$ per day, given without either enteric coating or antacid, experienced symptoms and signs of reduced absorptive ability, probably indicating a toxic effect on the intestinal mucosa from this dose. It is probable that Albright, Reifenstein, and Forbes, who treated an osteoporotic subject with 30 to 90 mg fluoride per day (20) were dealing with a similar toxic effect on gastrointestinal absorption, inasmuch as they observed increased fecal excretion and a negative change of balance of nitrogen as well as of calcium and phosphorus.

The joint pain seemed definitely related to treatment and appeared clinically to be an exacerbation of previously symptomatic degenerative arthritis. Tracer studies show that fluoride is concentrated slightly in cartilage and tendon, compared to blood and other soft tissues $(21,22)$. Although direct evidence is lacking, the joint pain 
may be related somehow to concentration of fluoride in structures around the joint.

Our present studies show that $1 \mathrm{mg}$ fluoride per $\mathrm{kg}$ per day causes calcium retention, but do not give information as to the minimal effective dose. That half of this amount (the dose we are now using) may be effective is suggested by the work of Purves, who has reported metabolic effects from about $0.5 \mathrm{mg}$ per $\mathrm{kg}$ per day in treatment of subjects with Paget's disease (6).

Mechanism of fluoride effect. The positive change in calcium balance occurred because of reduced excretion of calcium in both stools and urine. The urinary changes were not accounted for by altered glomerular filtration or reduction of total concentration of calcium in plasma, and the reason, particularly for the marked initial reduction of calcuria of some patients, is not clear. Decreased fecal calcium was seen in all subjects whose calcium balance showed a positive change during treatment, and, except for H.L., in none of those who did not. This may be interpreted as the result either of increased gastrointestinal absorption, as suggested by Bernstein and co-workers (7), or reduced excretion of endogenous calcium, or both. Although the balance data do not allow a conclusion as to which of these possibilities is more likely, the latter seems more in keeping with the frequent finding of a reduction of excretion of calcium in urine of patients treated with fluoride.

In spite of an enormous amount of toxicological study in animals (3), no reliable concept of the mechanism of fluoride action on bone can be formulated. It appears to be quite complex, combining physical and cytological effects, with different histologic abnormalities depending upon the dose of fluoride. Probably because of the structural similarity between fluorapatite and hydroxyapatite of bone, fluoride is concentrated in this tissue, presumably causing cells of bone to be exposed to a greater concentration of fluoride than cells of other tissues. Fluoride in large excess of the concentration found in body fluids is known to be a potent inhibitor of numerous enzyme activities, including phosphatases, lipases, and enolase $(3,23)$, but how it alters bone cell function is not clear. The observed changes in fluorotic human bone, of stimulated growth of architecturally abnormal periosteal, endosteal, and trabecular bone $(2,3,19)$, and probably also decreased osteoclastic activity (2), are clearly the result of a cytological effect. In addition, there is evidence to suggest that bone crystals coated with fluoride (as fluorapatite) have fewer defects and are less reactive than normally (24). Such physical changes could well depress bone resorption and thus cause an increased skeletal mass.

Clinical application. The major objective of this study was to show whether or not fluoride causes calcium retention when given to subjects with metabolic bone disease. If this occurs in the absence of extraskeletal calcification, it may be assumed that the rate of bone formation is accelerated or the rate of resorption reduced, or both, but not necessarily that the strength of the skeleton has been increased. Although data as to strength of fluorotic bone of humans appear to be lacking, and such data from animals given a comparable dose of fluoride are scanty, they suggest that bone strength is normal $(25,26)$.

The fact that fluoride administration results in retention of calcium by subjects with several types of osteoporosis, with or without concurrent testosterone therapy, as well as by patients with Paget's disease, suggests that it occurs because of a general effect on bone metabolism rather than from interference with the metabolic abnormality of any given disease process.

The positive change of calcium balance, which was usually about $150 \mathrm{mg}$ per day, is significantly less than that often observed when normal subjects or osteoporotic patients are treated with estrogen $(16,27,28)$ or by supplementation of the dietary intake of calcium (29-32). However. although it is unlikely that an agent would be useful as a treatment of osteoporosis if it did not cause calcium retention, it does not follow that the best agent causes the greatest retention. Not only does fluoride cause significant retention of calcium when given for 3 to 18 months, but it is the only agent suitable for prolonged administration to humans known to increase the density of the skeleton.

Purves, in a recently published study of effect of fluoride in Paget's disease (6), has noted symptomatic improvement, marked reduction of the abnormal uptake of $\mathrm{Ca}^{47}$ by the involved portions of the skeleton, and changes in calcium balance similar to those we have reported. These findings, 
and the reduction of the abnormally high rate of excretion of hydroxyproline observed in one of our subjects, suggest the possibility that, in addition to a general effect on the skeleton which tends to cause calcium retention, fluoride may directly affect the metabolic abnormality of Paget's disease. A somewhat comparable reduction of activity of this disease has been brought about by cortisone (33) and aspirin (34), as indicated by symptomatic remissions, and changes of hydroxyproline excretion in urine and calcium balance that are comparable to those shown here.

The demonstration of calcium retention in osteoporotic subjects treated with fluoride brings up the question of whether or not a smaller dose of fluoride, given for years before substantial demineralization usually is seen, might reduce the incidence or severity of osteoporosis. This cannot be resolved by showing response to therapy of patients who already have the disease, but can best be examined by study of incidence of osteoporosis in groups of subjects with backgrounds that are similar except for different levels of fluoride exposure. Although there is work which suggests a possible relationship between level of fluoride intake and incidence of osteoporosis (35), it is inconclusive. It would seem of considerable importance that a study specifically designed to test this point be carried out.

\section{Summary}

1) Detailed clinical and biochemical studies have been carried out on six subjects before and during treatment with about $1 \mathrm{mg}$ fluoride per $\mathrm{kg}$ body weight per day (given by mouth as sodium fluoride) for 5 to 75 weeks.

2) External balance of calcium, phosphorus, nitrogen, and fluoride was measured in each case. In four subjects, all in negative calcium balance during the control period, these measurements were carried out under conditions that allowed assessment of the effect of fluoride on calcium balance. Of three patients with primary osteoporosis, two retained calcium during treatment, showing an average positive change of $173 \mathrm{mg}$ per day. A third subject did not respond. The fourth subject, with Paget's disease, also retained calcium during treatment.

3) Urinary excretion of calcium in several subjects fell to very low values, and fecal excretion of calcium was usually reduced during treatment with fluoride.

4) Three subjects, who had had repeated attacks of aching joint pain for many years, had an increased amount of this pain. There were no other symptoms and no biochemical evidence of toxic effect in any patient.

5) On the basis of this and other published work, it is concluded that further clinical trial of fluoride is warranted in patients with osteoporosis and Paget's disease.

\section{Appendix}

Primary osteoporosis. M.H., an 84-year-old woman, had a compression fracture of the first lumbar vertebra at the age of 72 . She was treated intermittently with diethylstilbestrol and testosterone proprionate until 5 months before admission but has been given none since. Severe demineralization of the spine and several vertebral compression fractures were shown by $X$ ray. She was studied during a control period and then for the first 7 and last 4 of 36 weeks of treatment with $1.0 \mathrm{mg}$ fluoride per kg per day. After the first 2 weeks of treatment, she was given $20 \mathrm{ml}$ aluminum hydroxide gel per day.

F.F., a 62-year-old male, had X-ray evidence of compression of the eighth thoracic vertebra when 44 years old. He was treated with testosterone proprionate for 5 years, without improvement, and was given testosterone $17 \beta$-cyclopentaneproprionate, $400 \mathrm{mg}$ every month for 7 months before and throughout the study. Our $\mathrm{X}$ rays showed marked demineralization of pelvis and spine with compression fractures of the eighth and twelfth thoracic and first lumbar vertebrae. He was studied before and twice during 75 weeks of treatment with $1.1 \mathrm{mg}$ fluoride per kg per day. He felt markedly improved, experiencing relief of back pain.

A.S., a 61-year-old male was found to have compression of the last two thoracic vertebrae when he was 48 years old. He was given $200 \mathrm{mg}$ testosterone $17 \beta$-cyclopentanepropionate every 2 weeks for 2 years before and throughout the period of study. Our $X$ rays showed vertebral demineralization with deformity of the end plates of several vertebrae. He was treated for 9 weeks with $1.0 \mathrm{mg}$ fluoride per $\mathrm{kg}$ per day without symptomatic change.

R.K., a 70-year-old male with a history of back pain and episodic aching pain in the knees and ankles for 10 years, was found 6 months before admission to have compression deformities of the last thoracic and fourth lumbar vertebrae and a rib fracture. During the first test of fluoride effect he was given a low calcium intake of $200 \mathrm{mg}$ per day. After discharge he was placed upon a normal diet and $200 \mathrm{mg}$ testosterone $17 \beta$-cyclopentaneproprionate every other week until completion of the final study. He was readmitted 7 months later and studied during a second control period and for the last 4 of 32 weeks of treatment with $0.7 \mathrm{mg}$ of fluoride per $\mathrm{kg}$ per 
day. During the last 3 months he had progressively increasing knee pain on weight bearing.

Steroid ostcoporosis. H. L., a 52-year-old male gave a history of intermittent aching pain in the joints of the extremities and of increasingly severe and frequent asthma for 23 years. He had been treated with prednisone for 6 years and for the past year had taken 20 $\mathrm{mg}$ daily. Our $\mathrm{X}$ rays showed slight biconcave deformity of several lumbar vertebrae. The patient was studied before and at the end of 7 months of treatment with $0.9 \mathrm{mg}$ fluoride per $\mathrm{kg}$ per day. During the interim his asthma had been severe, and he had usually taken $30 \mathrm{mg}$ predisone daily. He had increasing knee pain, especially on weight bearing during the last 2 months of treatment. Fat absorption was decreased when measured both before and during treatment.

Paget's disease. E.M., a 61-year-old female, had a 10year history of aching pain in the extremities and spine. Osteitis deformans had been recognized because of typical X-ray changes of the skull and pelvis 10 years before. The X-ray appearance of the spine was normal. She was studied before and at the end of 10 months of treatment with $1.0 \mathrm{mg}$ fluoride per $\mathrm{kg}$ per day. She experienced pain in the ankle upon weight bearing during the last month of treatment.

\section{Acknowledgments}

It is a pleasure to acknowledge the skillful and valuable assistance of Miss M. Ishi, research dietician, Miss S. Riverman, head nurse, Mrs. F. Kusumi, and Messrs. H. Fellows, R. Haller, and S. Trenholme, chemists. We wish to thank Dr. Elmer M. Plein of the College of Pharmacy, University of Washington, for preparing the enteric-coated tablets of sodium fluoride used in this study.

\section{Addendum}

\section{Plasma Fluoride Concentrations of Pa- tients Treated with Sodium Fluoride *}

W. D. Armstrong, Leon Singer, John Ensinck, And Clayton Rich

(From the Department of Biochemistry, Medical School, University of Minnesota, Minneapolis, Minn., the Department of Medicine, University of Washington School of Medicine, and the Veterans Administration Hospital, Seattle, Wash.)

Plasma was harvested from heparinized blood drawn before breakfast from patients described in this paper. Specially washed syringes and glassware (1) were supplied to the Seattle workers to reduce the possibility of fluoride contamination, and the plasma was sent frozen to Minneapolis. The analyses for fluoride were carried

* These studies were supported in part by grants from the U. S. Public Health Service (grants DE-01850 and AM-04701). out by the method of Singer and Armstrong (1). The table identifies the patients, briefly summarizes the fluoride treatments, and gives the results of the fluoride determinations.

With the exception of patients R.K. and M.H. no large increases in plasma fluoride concentration were noted, and in these subjects there was only a 4- and 5-fold change, in spite of a 50 - to 100 -fold increase in intake of fluoride. The remaining patients had only slight analytically significant elevations of plasma fluoride content.

These results were obtained with plasma samples drawn some hours after the last dose of fluoride, and they indicate the plasma fluoride contents at equilibrium conditions after the operation of the homeostatic mechanisms of renal excretion and of skeletal sequestration of this ion. Other work (2) has indicated that about $10 \%$ of an oral dose of fluoride is present in the entire plasma volume 1 hour after fluoride ingestion in water.

\section{References}

1. Singer, L., and W. D. Armstrong. Determination of fluoride in blood serum. Analyt Chem. 1959, 31, 105.

2. Carlson, C. H., W. D. Armstrong, and L. Singer. Distribution and excretion of radiofluoride in the human. Proc. Soc. exp. Biol. (N. Y.) 1960, 104, 235.

Fluoride concentration of human plasma

\begin{tabular}{|c|c|c|c|c|c|}
\hline \multirow[t]{2}{*}{ Patient } & \multicolumn{2}{|c|}{$\begin{array}{c}\text { Plasma } \\
\text { fluoride } \\
\text { content } \\
\text { Control } \\
\text { levels }\end{array}$} & \multirow[t]{2}{*}{$\begin{array}{l}\text { Duration } \\
\text { of treat- } \\
\text { ment }\end{array}$} & \multirow{2}{*}{\multicolumn{2}{|c|}{ 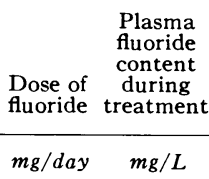 }} \\
\hline & $m g$ & & & & \\
\hline R. K. & 0.21 & 0.17 & $\begin{array}{r}3 \text { days } \\
10 \text { days }\end{array}$ & $\begin{array}{l}100 \\
100\end{array}$ & $\begin{array}{l}0.79 \\
0.85\end{array}$ \\
\hline . & & & $\begin{array}{l}\text { Treatment } \\
35 \text { weeks } \\
38 \text { weeks }\end{array}$ & vithdrawn & $\begin{array}{l}0.30 \\
0.24\end{array}$ \\
\hline M.H. & 0.26 & 0.38 & $\begin{array}{l}3 \text { days } \\
14 \text { days } \\
33 \text { weeks } \\
34 \text { weeks }\end{array}$ & $\begin{array}{l}50 \\
50 \\
50 \\
50\end{array}$ & $\begin{array}{l}0.65 \\
1.77 \\
0.45 \\
0.48\end{array}$ \\
\hline F.F. & 0.14 & 0.19 & 5 days & 50 & 0.23 \\
\hline E.M. & 0.21 & 0.19 & $\begin{array}{c}1 \text { day } \\
2 \text { days } \\
12 \text { weeks }\end{array}$ & $\begin{array}{l}60 \\
60 \\
60\end{array}$ & $\begin{array}{l}0.34 \\
0.30 \\
0.25\end{array}$ \\
\hline H.L. & 0.21 & 0.27 & $\begin{array}{l}2 \text { days } \\
16 \text { weeks } \\
24 \text { weeks }\end{array}$ & $\begin{array}{l}75 \\
75 \\
75\end{array}$ & $\begin{array}{l}0.27 \\
0.32 \\
0.28\end{array}$ \\
\hline
\end{tabular}

\section{References}

1. Moller, P. F., and S. V. Gudjonsson. Massive fluorosis of bones and ligaments. Acta radiol. (Stockh.) 1932, 13, 269.

2. Roholm, Kaj. Fluorine Intoxication: A Clinicalhygienic Study. London, H. K. Lewis, 1937.

3. Largent, E. J. Fluorosis. The Health Aspects of Fluorine Compounds. Columbus, Ohio State University Press, 1961. 
4. Rich, C., and J. Ensinck. Effect of sodium fluoride on calcium metabolism of human beings. Nature (Lond.) 1961, 191, 184.

5. Rich, C., and J. Ensinck. Effect of sodium fluoride in subjects with metabolic bone disease. Clin. Res. 1962, 10, 118.

6. Purves, M. J. Some effects of administering sodium fluoride to patients with Paget's disease. Lancet 1962, 2, 1188.

7. Bernstein, D. S., C. Guri, P. Cohen, J. J. Collins, and S. Tamvakopoulos. The use of sodium fluoride in metabolic bone disease. $\mathrm{J}$. clin. Invest. 1963, 42, 916.

8. Rich, C. The distribution of calcium given to human subjects by sustained intravenous infusion. J. clin. Endocr. 1960, 20, 147.

9. Consolazio, C. F., R. E. Johnson, and E. Marek. Metabolic Methods. Clinical Procedures in the Study of Metabolic Functions. St. Louis, C. V. Mosby, 1951.

10. Fiske, C. H., and Y. Subbarow. The colorimetric determination of phosphorus. J. biol. Chem. 1925, 66, 375.

11. Prockop, D. J., and S. Udenfriend. A specific method for the analysis of hydroxyproline in tistues and urine. Analyt. Biochem. 1960, 1, 228.

12. Van de Kamer, J. H., H. ten Bokkel Huinink, and H. A. Weyers. Rapid method for determination of fat in feces. J. biol. Chem. 1949, 177, 347.

13. Flagg, J. F. Analytical methods for determining uranium and fluorine in Pharmacology and Toxicology of Uranium Compounds, C. Voegtlin and H. C. Hodge, Eds. New York, McGraw-Hill, 1949, ch. 2.

14. Megregian, S. Rapid spectrophotometric determination of fluoride with zirconium-eriochrome cyanin R lake. Analyt. Chem. 1954, 26, 1161

15. Reifenstein, E. C., Jr., F. Albright, and S. L. Wells. The accumulation, interpretation, and presentation of data pertaining to metabolic balances, notably those of calcium, phosphorous, and nitrogen. J. clin. Endocr. 1945, 5, 367.

16. Albright, F., and E. C. Reifenstein, Jr. The Parathyroid Glands and Metabolic Bone Disease. Balitmore, Williams and Wilkins, 1948.

17. Black, M. M., I. S. Kleiner, and H. Bolker. The toxicity of sodium fluoride in man. N. Y. St. J. Med. 1949, 49, 1187.

18. Hodge, H. C., and F. A. Smith. Some public health aspects of water fluoridation in Fluoridation as a Public Health Measure, J. H. Shaw, Ed. Washington, D. C., American Association for the Advancement of Science, 1954, p. 79.

19. Singh, A., S. S. Jolly, B. C. Bansal, and C. C. Mathur. Endemic fluorosis. Epidemiological, clinical and biochemical study of chronic fluorine intoxication in Panjah (India). Medicine (Baltimore) 1963, 42, 229

20. Albright, F., E. C. Reifenstein, Jr., and W. H. Forbes. Effect of sodium fluoride on the meta- bolic data of a patient with idiopathic osteoporosis. Transaction Macy Conference on Metabolic Aspects of Convalescence 1944, 8, 20.

21. Wallace, P. C. The metabolism of $F^{18}$ in normal and chronically fluorosed rats. U. S. Atomic Energy Commission, 1953, Publication UCRL2196.

22. Carlson, C. H., L. Singer, and W. D. Armstrong. Radiofluoride distribution in tissues of normal and nephrectomized rats. Proc. Soc. exp. Biol. (N. Y.) 1960, 103, 418.

23. Boyer, P. D., H. Lardy, and K. Myrbäck. The Enzymes, 2nd ed. New York, Academic Press, 1961.

24. Zipkin, I., A. S. Posner, and E. D. Eanes. The effect of fluoride on the $x$-ray-diffraction pattern of the apatite of human bone. Biochim. biophys. Acta (Amst.) 1962, 59, 255.

25. Savchuck, W. B. Effects of strontium and fluoride on the repair of unreduced humeral fractures in the adult rat. J. Bone Jt Surg. 1957, 39A, 140.

26. Bell, G. H., and J. B. De V Weir. Physical properties of bone in fluorosis in Industrial fluorosis, a study of the hazard to man and animals near Fort William, Scotland. A report to the fluorosis committee. Memor. med. Res. Coun. (Lond.) 1949, 22, 85 .

27. Reifenstein, E. C., Jr., and F. Albright. The metabolic effects of steroid hormones in osteoporosis. J. clin. Invest. 1947, 26, 24.

28. Anderson, I. A. Postmenopausal osteoporosis, clinical manifestations, and the treatment with estrogens. Quart. J. Med. 1950, 19, 67.

29. Adams, M., W. M. Boothby, and A. M. Snell. Metabolic studies in osteoporosis. Amer. J. Physiol. 1935, 114, 383.

30. Shorr, E., and A. C. Carter. The value of strontium as an adjuvant to calcium in the remineralization of the skeleton in osteoporosis in man. Transaction Macy Conference on Metabolic Interrelations 1950, 2, 144.

31. Whedon, G. D. Effects of high calcium intakes on bones, blood and soft tissue : relationship of calcium intake to balance in osteoporosis. Fed. Proc. 1959, 18, 1112.

32. Harrison, M., R. Fraser, and B. Mullan. Calcium metabolism in osteoporosis. Lancet 1961, 1, 1015.

33. Albright, F., and P. H. Henneman. The suppression of Paget's disease with ACTH and cortisone. Trans. Ass. Amer. Phycns 1955, 68, 238.

34. Maurice, P. F., T. N. Lynch, C. H. Bastomsky, T. A. Dull, L. V. Avioli, and P. H. Henneman. Metabolic evidence for suppression of Paget's disease of bone by aspirin. Trans. Ass. Amer. Phycns 1962, 75, 208.

35. Leone, N. C., C. A. Stevenson, T. F. Hilbush, and M. C. Sosman. A roentgenologic study of a human population exposed to high-fluoride domestic water. Amer. J. Roentgenol. 1955, 74, 874. 